\title{
Regulation of gene expression by the HlyX protein of Actinobacillus pleuropneumoniae
}

\author{
Glenn A. Soltes† and Janet I. Maclnnes \\ Author for correspondence: Janet I. MacInnes. Tel: +1 5198244120 ext. 4731 . Fax: +1 5197670809. \\ e-mail: JMACINNES@OVCNET.UOGUELPH.CA
}

Department of Veterinary Microbiology and Immunology, University of Guelph, Guelph, Ontario, Canada N1G 2W1

\begin{abstract}
The hlyX gene of the swine pathogen Actinobacillus pleuropneumoniae and the $f$ r gene of Escherichia coli encode very similar proteins. The hlyX gene is able to complement $\Delta f n r$ mutations and will permit the growth of $E$. coli fnr strains in nitrate minimal salts medium under anoxic conditions. In addition, the hlyX gene product appears to induce the expression of a latent haemolytic activity as evidenced by the presence of a strong zone of haemolysis around $E$. coli $\left(h / y X^{+}\right)$colonies grown on bovine or ovine blood. In this study, the ability of the hlyX gene product to induce haemolytic activity and regulate expression of frdA and its own gene was examined in the presence of various carbon sources and in the presence and absence of iron; fnr was included for comparison. The HlyX protein was able to induce the synthesis of the latent $E$. coli haemolytic activity only under anoxic conditions. Haemolytic activity was highest during the late exponential phase and then levelled off in the stationary phase. The $h / y X$ gene product was able to activate the expression of a $\Phi\left(f r d A^{\prime}-\right.$ lacZ) in E. coli JRG1787 ( $\Delta$ fnr); however, the level of expression depended on carbon source, growth phase and copy number. Like fnr, the hlyX gene product appeared to affect its own synthesis but the nature and extent of regulation depended not only on the presence of oxygen but also on growth conditions.
\end{abstract}

Keywords: Actinobacillus pleuropneumoniae, HlyX protein, FNR, BTR, haemolytic activity

\section{INTRODUCTION}

The Gram-negative bacterium Actinobacillus pleuropneumoniae is an important pathogen of swine throughout the world (Nicolet, 1992). It can cause an acute, and often fatal, pleuropneumonia in pigs of all ages. Capsule, outer membrane proteins, lipopolysaccharide and three related RTX toxins have been implicated in the pathogenesis of this organism (Frey et al., 1993a, b; Inzana, 1991). The RTX toxins, now designated ApxI, ApxII and ApxIII, can damage neutrophils and macrophages (Frey et al., 1993b). ApxI and, to a lesser degree, ApxII, can also lyse red blood cells from several different species (Frey \& Nicolet, 1988; Rosendal et al., 1988). In addition to these toxins, $A$. pleuropneumoniae carries a gene which can confer a strong haemolytic phenotype on a variety of Escherichia coli K12 strains (Frey et al., 1989; Lian et al., 1989). This gene, bly $X(c f p)$, does not appear to encode a haemolysin

†Present address: Cangene Corp., 3403 American Dr., Mississauga, Ontario, Canada L4V 1 T4.

Abbreviations: CIP, calf intestinal phosphatase; MU, Miller units. per se but, rather, it seems to induce a latent haemolysin in E. coli.

Consistent with this notion, the deduced amino acid sequence of the HlyX protein does not share any homology with that of any known haemolysin or cytotoxin (MacInnes et al., 1990). It does, however, have a high degree of similarity with the $E$. coli protein FNR (Shaw \& Guest, 1982). FNR belongs to a growing family of transcriptional regulators with a helix-turn-helix DNAbinding domain. This family includes the CRP (cAMP receptor protein) of $E$. coli, FnrN and FnrK from Rbizobium leguminosarum and Rbizobium meliloti, respectively, and ANR from Pseudomonas aeruginosa (Batut et al., 1989; Colonna-Romano et al., 1990; Galimand et al., 1991; Sawers, 1991; Spiro \& Guest, 1990). FNR homologues often function as oxygen sensors, and they can regulate a variety of genes involved in such diverse processes as anaerobic carbon metabolism and respiration, nitrogen fixation or luciferase expression (reviewed by Spiro, 1994).

The FNR protein has been shown to bind to specific sequences in the promoters of its target genes (Green et 
al., 1991; Sharrocks et al., 1991). Under anoxic conditions, FNR activates the transcription of at least 15 genes that code for enzymes which are required for anaerobic electron transport to alternative terminal electron acceptors such as nitrate or fumarate (Spiro \& Guest, $1990,1991)$. FNR-activated targets include the narGHJI operon, which encodes nitrate reductase, the frd $A B C D$ operon, which encodes fumarate reductase, $p f l$, which encodes pyruvate formate-lyase, and the $d m s A B C$ operon, which encodes DMSO reductase (reviewed by Spiro \& Guest, 1990). It is also able to repress the synthesis of cytochrome $o$ oxidase (cyo $A B C D$ ), NADH dehydrogenase II $(n d b)$ and manganese-containing superoxide dismutase (sod A) (Cotter et al., 1990; Hassan \& Sun, 1992; Spiro et al., 1989). Although there has been some debate, FNR is also thought to negatively regulate its own synthesis under anoxic conditions (Jones \& Gunsalus, 1985; Pascal et al., 1986; Spiro \& Guest, 1987, 1990). Regulation of gene expression by FNR requires four iron-binding cysteine residues, and it has been speculated that FNR changes from an active to inactive conformation as the iron molecule is oxidized from ferrous to ferric iron under aerobic conditions (Green et al., 1991).

The bly $X$ gene shares considerable sequence homology with $f n r$, including regions thought to be important in regulation. HlyX has also been shown to activate the expression of FNR targets such as the nar $A B C D$ operon and $F F-m e l \mathrm{R}-l a c Z$, which contains a semi-synthetic promoter with a perfect FNR recognition sequence (Green et al., 1992; MacInnes et al., 1990). Despite sequence similarities, there do appear to be both quantitative and qualitative differences in the way these proteins regulate gene expression (Green et al., 1992). Therefore, the purpose of these experiments was to look, in detail, at the ability of Hly X to regulate the well-studied FNR target, $f r d A^{\prime}-l a c Z$, and the latent E. coli haemolysin. We also wanted to determine if HlyX expression was autoregulated and to confirm that iron was required for its activity.

\section{METHODS}

Bacterial strains and growth conditions. The bacterial strains used in this study and their sources are listed in Table 1. For routine culture, cells were grown in Luria-Bertani (LB) medium at $37^{\circ} \mathrm{C}$ or, for $\lambda \mathrm{cI} 857$ lysogens, at $30^{\circ} \mathrm{C}$ in the presence of the appropriate antibiotic. For growth and promoter fusion studies, cultures were grown in minimal salts medium (Lambden \& Guest, 1976) supplemented with $0.6 \%$ (w/v) fumarate or $0.4 \%(\mathrm{w} / \mathrm{v})$ nitrate and $0.2 \%(\mathrm{w} / \mathrm{v})$ glucose or $0.2 \%(\mathrm{v} / \mathrm{v})$ glycerol. A $1 \%(\mathrm{v} / \mathrm{v})$ inoculum of cells grown in minimal medium was used to inoculate cultures. When anoxic conditions were required, media were bubbled with $\mathrm{N}_{2}$ for $1 \mathrm{~h}$ immediately before use. Anoxic cultures were grown in $10 \mathrm{ml}$ aliquots in sealed $\mathrm{N}_{2}$-purged $12 \mathrm{ml}$ serum vials. Aerobic cultures were grown in $10 \mathrm{ml}$ aliquots in $125 \mathrm{ml}$ Erlenmeyer flasks on a rotating shaker at 125 r.p.m. When required, free $\mathrm{Fe}^{3+}$ and $\mathrm{Fe}^{2+}$ were removed by the addition of $10-50 \mu \mathrm{M} 1,10$-phenanthroline or $2 \%(\mathrm{w} / \mathrm{v})$ Chelex-100 beads. Iron-depleted media were prepared using acid-treated glassware and Milli-Q purified water.

Calculation of doubling times. When grown under anoxic conditions, cultures were sampled approximately every $3 \mathrm{~h}$ under a continuous flow of $\mathrm{N}_{2}$; aerobic cultures were sampled every $30 \mathrm{~min}$. The doubling times of the cultures were calculated from the linear portion of the logarithmic plots of growth curves according to Koch (1981). The data shown are means $\pm \mathrm{SE}$; they are representative of three experiments, each with three replicates.

$\boldsymbol{\beta}$-Galactosidase and haemolytic activity assays. The $\beta$-galactosidase assays were performed essentially as described by Miller (1972). Expression of the frd $A^{\prime}-$ lac $Z$ promoter fusion was measured after $5 \mathrm{~h}$ of aerobic growth and 18-22 $\mathrm{h}$ of anoxic growth. The data shown are means $\pm \mathrm{SE}$; they are representative of three experiments, each with three replicates. Haemolytic activity assays were done using a modification of the method of Rosendal et al. (1988). Since previous experiments had shown that the haemolytic activity remains within the cell, it was only necessary to measure haemolytic activity in the cell pellet. All measurements were done on four replicates at each time point. The data shown are means $\pm S E$; they are representative of three independent experiments.

Construction of $h l y X$ recombinant plasmids. Unless otherwise indicated, chemicals were purchased from Fisher Scientific and enzymes were purchased from Boehringer Mannheim. Recombinant plasmids were constructed using standard procedures (Sambrook et al., 1989). The $6 \mathrm{~kb}$ HindIII fragment of pA44 (Lian et al., 1989), which carries the blyX gene and flanking sequences, was gel purified and ligated to HindIIIdigested, CIP-treated pBR322 DNA to create a tetracycline resistant bly $X$ recombinant, pGSG2. A blyX promoter lac $Z$ fusion was created using the plasmid pCB267, which carries a multiple cloning site followed by strong translation termination sequences in all three reading frames (Schneider \& Beck, 1986). These sequences are upstream of a promoterless lac $Z$ cistron

Table 1. E. coli strains, bacteriophage and plasmids

\begin{tabular}{|c|c|c|}
\hline & Genotype & Source or reference \\
\hline \multicolumn{3}{|l|}{ Strains } \\
\hline JRG1728 & $\begin{array}{l}\mathrm{MC} 1000 \\
\Delta(\text { tyrR-fnr-rac-try })\end{array}$ & Spiro \& Guest (1988) \\
\hline JRG1787 & $\begin{array}{l}\mathrm{MC} 1000 \\
\Delta(\text { tyrR-fnr-rac-try }) \\
\lambda \Phi\left(\text { frd } A p^{\prime}-l a c Z\right)\end{array}$ & Spiro \& Guest (1987) \\
\hline \multicolumn{3}{|l|}{ Phage } \\
\hline$\lambda \mathrm{RZ5}$ & $\lambda^{\prime} b l a^{+} ' \operatorname{lac} Z^{+} \operatorname{lac} Y^{+}$ & R. Zagursky, unpublished \\
\hline$\lambda$ GSG10 & $\begin{array}{l}\lambda b l a^{+} \Phi\left(b l y X p^{\prime}-l a c Z\right)^{+} \\
\quad l a c Y^{+}\end{array}$ & This work \\
\hline \multicolumn{3}{|l|}{ Plasmids } \\
\hline pGEM4 & $b l a^{+}$ & $\begin{array}{l}\text { Promega Corp., Madison, } \\
\text { Wisconsin }\end{array}$ \\
\hline pBR322 & blat tet $^{+}$ & Bolivar et al. (1977) \\
\hline pA44 & $b l a^{+} b l y X^{+}$ & Lian et al. (1989) \\
\hline pT51 & $b l a^{+} b l y X^{+}$ & Lian et al. (1989) \\
\hline pGS24 & $b l a^{+} f n r^{+}$ & Shaw \& Guest (1982) \\
\hline pCB267 & bla ${ }^{+}{ }^{\prime} l a c Z^{+}{ }^{\prime}$ pho $A^{+}$ & Schneider \& Beck (1986) \\
\hline pGSG5 & $b l a^{+} \Phi\left(b l y X p^{\prime}-l a c Z\right)^{+}$ & This work \\
\hline pGSG3 & $b l a^{+} \Phi\left(b l y X p^{\prime}-l a c Z\right)^{+}$ & This work \\
\hline pGSG2 & $t e t^{+} b l y X^{+}$ & This work \\
\hline
\end{tabular}


with an intact Shine-Dalgarno sequence. A $300 \mathrm{bp} S_{s p I}$ fragment from pT51 was gel purified and ligated to HindIIIdigested pCB267 which had been made blunt-ended using mung bean nuclease. The $300 \mathrm{bp}$ fragment carries $99 \mathrm{bp}$ of sequence upstream from the putative transcription start site of the blyX gene and encodes the first 42 amino acids of the Hly X protein (MacInnes et al., 1990). One recombinant, which had a single copy of the $300 \mathrm{bp}$ insert in the correct orientation, was selected and designated pGSG5. A plasmid construct with $\Phi(b l y X p$ $l a c Z)$ and bla transcribed in opposite directions was required for construction of an $E$. coli $\lambda \mathrm{RZ5}(\Phi($ bly $X p-l a c Z))$ lysogen. Plasmid pGSG5 DNA was digested with PstI and the $4 \mathrm{~kb}$ fragment, which carries the blyXp-lacZ promoter fusion, was purified. The $4 \mathrm{~kb}$ fragment was ligated to PstI-digested, CIPtreated pGEM4 (Promega). One recombinant with the $b l y X p$-lac $Z$ fusion in the correct orientation was identified and designated pGSG3.

Construction of $\lambda$ GSG10, containing $\Phi(h / y X p-l a c z)$. Recombinant phage containing a $b l y X p$-lac $Z$ fusion were created by a double crossover event between $\lambda R Z 5$ containing partial bla and lac $Z$ genes and pGSG3, which contains $\Phi($ bly Xp-lacZ) and an intact bla gene. A high-titre lysate of $\lambda R Z 5$ was used to infect E. coli JRG1728(pGSG3). Following infection, a lysate containing both wild-type ( $\mathrm{Lac}^{-} \mathrm{Ap}^{\mathrm{s}}$ ) and recombinant $\lambda \mathrm{RZ} 5$ $\left(\mathrm{Lac}^{+} \mathrm{Ap} \mathrm{p}^{\mathrm{r}}\right)$ was recovered and used to infect $E$. coli JRG1728 under conditions that favoured lysogeny (Casadaban, 1976). Putative $\Phi(b l y X p-l a c Z)$ lysogens were screened in the presence of $75 \mu \mathrm{g}$ ampicillin $\mathrm{ml}^{-1}$ and $50 \mu \mathrm{g}$ 5-bromo-4-chloro-3-indolyi $\beta$-D-galactopyranoside $\mathrm{ml}^{-1}$. Six blue, $A \mathrm{p}^{\mathrm{r}}$ colonies were obtained and shown to contain prophage by cross-streaking with wild-type phage. Bacteriophage were induced from one of the lysogens, E. coli JRG1728( $\lambda$ GSG10), and characterized further by restriction mapping and Southern blotting. The recombinant phage $\lambda$ GSG10 was again introduced into the chromosome of E. coli JRG1728 by lysogeny. One lysogen, shown to contain a single prophage by Southern blotting, was selected for the autoregulation studies.

\section{RESULTS}

\section{Regulation of haemolytic activity by the HlyX protein}

Haemolytic activity in E. coli JRG1728 $(\Delta f n r)$ in the presence of plasmids pT51 (blyX), pGS24 (fnr) or pBR322 was measured quantitatively. In glycerol-nitrate minimal salts medium, haemolytic activity was detected only in the presence of the HlyX protein, and only under anoxic conditions (Fig. 1). The activity peaked in the late exponential phase and dropped slightly during the stationary phase of growth. No haemolytic activity could be detected in E. coli JRG1728 ( $\Delta f n r)$ with plasmids pGS24 (fnr) or pBR322 grown under either aerobic or anoxic conditions.

\section{Doubling times of $E$. coli JRG1728 in minimal salts medium}

The doubling time of E. coli JRG1728 $(\Delta f n r)$ in the presence of plasmids p T51 (blyX), pGS24 ( fnr) or pBR322 was measured in minimal salts medium supplemented with fumarate or nitrate as the terminal electron acceptor and glycerol or glucose as the carbon source (Table 2). The doubling times were shortest with oxygen as the terminal electron acceptor regardless of the carbon source or the presence of HlyX or FNR. As shown previously, either Hly X or FNR was required for growth of JRG1728 in glycerol-nitrate minimal salts medium under anoxic conditions. By contrast, with this same medium containing fumarate, neither HlyX nor FNR was needed; however, FNR did enhance growth. When glucose rather than glycerol was present as the carbon source, neither HlyX nor FNR had a significant effect on growth.

\section{Regulation of frdA'-lacZ expression by HlyX and FNR}

Expression of $\operatorname{frd} A^{\prime}-\mathrm{lac} Z$ was measured under aerobic and anoxic conditions in glycerol-fumarate minimal salts medium using E. coli JRG1787 ( $\left.\Phi\left(f r d A^{\prime}-l a c Z\right) \Delta f n r\right)$ in the presence and absence of Hly X; FNR was included for comparison (Table 3). Under anoxic conditions, the HlyX

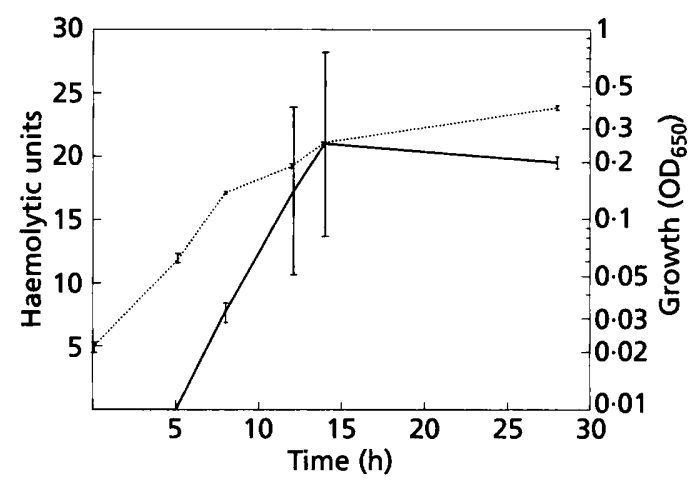

Fig. 1. Growth and haemolysin titres of $E$. coli JRG1728 ( $\Delta f n r)$ with plasmid pT51 $\left(h / y X^{+}\right)$. Cells were grown under anoxic conditions in glycerol-nitrate minimal salts medium at $30^{\circ} \mathrm{C}$. No haemolytic activity was detected under aerobic conditions or in E. coli JRG1728 with plasmids pBR322 or pGS24 $\left(f n r^{+}\right)$. Haemolytic units; $\cdots \cdots, \mathrm{OD}_{650}$.

Table 2. Doubling times of $E$. coli JRG1728 $\Delta$ fnr with PT51, pGS24 or pBR322 grown at $30^{\circ} \mathrm{C}$ under aerobic and anoxic conditions in minimal salts medium with glycerol and fumarate, glucose and fumarate and glycerol and nitrate

\begin{tabular}{|c|c|c|c|}
\hline \multirow[t]{2}{*}{ Medium } & \multirow[t]{2}{*}{ Plasmid } & \multicolumn{2}{|c|}{ Doubling time (h) } \\
\hline & & Aerobic & Anoxic \\
\hline Glycerol + fumarate & $\begin{array}{l}\text { pT51 }\left(b l y X^{+}\right) \\
\text {pGS24 }\left(f n r^{+}\right) \\
\text {pBR322 }\end{array}$ & $\begin{array}{l}2 \cdot 0 \pm 0 \cdot 1 \\
2 \cdot 1 \pm 0 \cdot 1 \\
2 \cdot 2 \pm 0 \cdot 1\end{array}$ & $\begin{array}{r}10 \cdot 6 \pm 0 \cdot 2 \\
7 \cdot 8 \pm 0 \cdot 2 \\
10 \cdot 0 \pm 0 \cdot 4\end{array}$ \\
\hline Glucose + fumarate & $\begin{array}{l}\text { p'51 }\left(\text { bly } X^{+}\right) \\
\text {pGS24 }\left(f n r^{+}\right) \\
\text {pBR322 }\end{array}$ & $\begin{array}{l}1 \cdot 6 \pm 0 \cdot 1 \\
1 \cdot 6 \pm 0 \cdot 1 \\
1 \cdot 9 \pm 0 \cdot 1\end{array}$ & $\begin{array}{l}4.7 \pm 0.6 \\
3 \cdot 2 \pm 0 \cdot 4 \\
5.0 \pm 0.4\end{array}$ \\
\hline Glycerol + nitrate & $\begin{array}{l}\text { pT51 }\left(b l y X^{+}\right) \\
\text {pGS24 }\left(f n r^{+}\right) \\
\text {pBR322 }\end{array}$ & $\begin{array}{l}2 \cdot 3 \pm 0 \cdot 1 \\
2 \cdot 4 \pm 0 \cdot 1 \\
2 \cdot 5 \pm 0 \cdot 1\end{array}$ & $\begin{array}{l}8 \cdot 7 \pm 0 \cdot 3 \\
6 \cdot 8 \pm 0 \cdot 3 \\
21 \pm 1 \cdot 0\end{array}$ \\
\hline
\end{tabular}


Table 3. Expression of frd'-lacZ in E. coli JRG1787 $\left(\Phi\left(f r d^{\prime}-l a c Z\right) \Delta f n r\right)$ with plasmids pT51 (hlyX $\left.X^{+}\right)$, pGSG2 $\left(h l y X^{+}\right)$, pGS24 $\left(f n r^{+}\right)$or pBR322

Cells were grown at $30^{\circ} \mathrm{C}$ in minimal salts medium with glycerol and fumarate.

\begin{tabular}{|lrc|}
\hline Plasmid & \multicolumn{2}{c|}{ frd'-lacZ expression (MU) } \\
\cline { 2 - 3 } & Anoxic & Aerobic \\
\hline pT51 (pGEM4 derivative) & $810 \pm 31$ & $230 \pm 5$ \\
pGSG2 (pBR322 derivative) & $590 \pm 32$ & $180 \pm 3$ \\
pGS24 (pBR322 derivative) & $1700 \pm 54$ & $280 \pm 5$ \\
pBR322 & $250 \pm 14$ & $95 \pm 1$ \\
\hline
\end{tabular}

protein activated frd $A^{\prime}-$ lac $Z$ expression two- to threefold as compared to the vector control when expressed from pGSG2. Somewhat higher levels of expression were obtained when the HlyX protein was expressed from plasmid pT51. FNR activated frd $A^{\prime}-l a c Z$ expression about sixfold. Under aerobic conditions, the expression of frd $A^{\prime}-$ lac $Z$ in the presence of the HlyX or FNR proteins was comparable to expression under anoxic conditions with the vector alone.

The effects of different carbon sources on the regulation of the frd $A^{\prime}-$ lac $Z$ expression by the HlyX and FNR proteins were also examined at various times (Fig. 2). Under anoxic conditions in fumarate minimal salts medium with glucose, $\operatorname{frd} A^{\prime}-$ lac $Z$ expression was maximal at $4 \mathrm{~h}$ at 7 times and 13 times the vector control levels for the HlyX and FNR proteins, respectively. The level of frd $A^{\prime}-$ lac $Z$ expression was slightly lower at 8 and $18 \mathrm{~h}$. In medium containing glycerol, frd $A^{\prime}-$ lac $Z$ expression increased over time. In glycerol medium, the maximal level of frd $A^{\prime}-$ lac $Z$ expression was about 1.4-fold higher than that detected in glucose medium.

\section{Regulation of expression of a chromosomal $h l y X$ promoter fusion in JRG1728 ( GSG10 $\Phi(h / y X p-l a c Z)$ )}

In order to study the regulation of expression of a single copy of the bly $X$ gene, the $b l y X p$-lac $Z$ fusion from $p G S G 3$ was transferred to $\lambda \mathrm{RZ} 5$ by homologous recombination to produce $\lambda$ GSG10 ( $\Phi($ bly $X p$-lacZ $))$, which was then introduced into the chromosome of E. coli JRG1728 ( $\Delta \mathrm{fnr}$ $\Delta l a c)$. The expression of the $b l y X p$-lac $Z$ fusion in cells with pGSG2 (blyX) or pBR322 was examined (Table 4). The expression of the bly $X p-l a c Z$ promoter fusion could not be detected using the Miller (1972) assay in cells grown to late exponential or stationary phase in LB medium or in glycerol-fumarate minimal salts medium. In early exponential phase in both media, expression could be detected in cells containing pBR322 but not in cells with pGSG2 $\left(b l y X^{+}\right)$. The level of expression varied with the growth conditions, however. In minimal medium, no
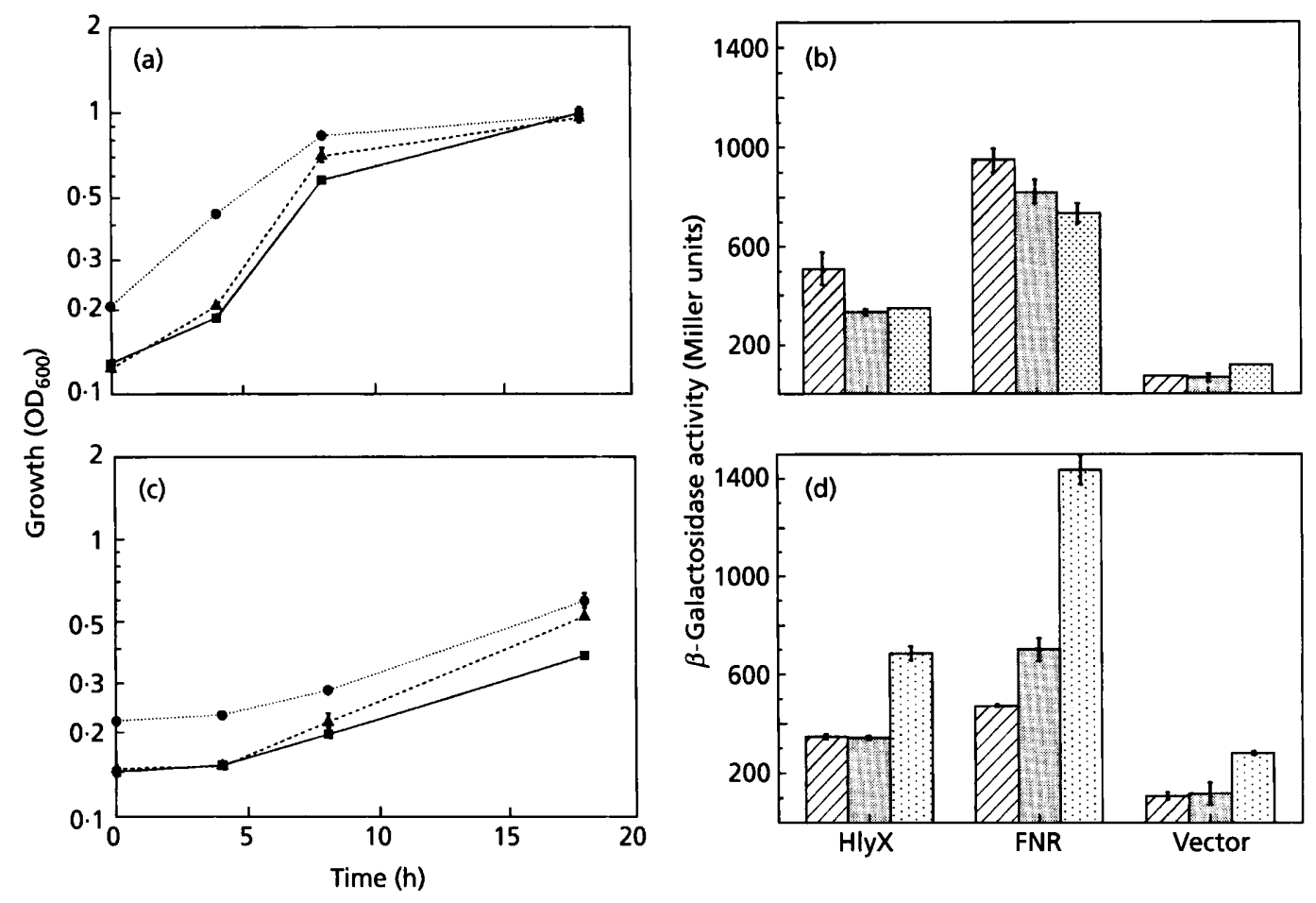

Fig. 2. Growth of $E$. coli JRG1787 ( $\left.\Phi\left(f r d A^{\prime}-l a c Z\right) \Delta f n r\right)(a, c)(-\square-$, Hlyx; -- $\Delta--$, FNR; $\cdots \cdots$, vector) and expression

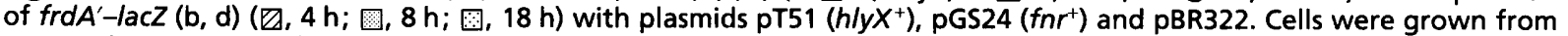
4 to $18 \mathrm{~h}$ at $30{ }^{\circ} \mathrm{C}$ under anoxic conditions in minimal salts medium with fumarate and $0.2 \%$ glucose $(a, b)$ or $0.2 \%$ glycerol $(c, d)$ as the carbon source. 
Table 4. Expression of a chromosomal hlyX promoter fusion, JRG1728( $\lambda$ GSG10 $\Phi(h l y X p-l a c Z) \Delta f n r)$

\begin{tabular}{|llcc|}
\hline Medium & \multicolumn{1}{c}{ Plasmid } & $\begin{array}{c}\text { hly } \boldsymbol{X p} \text {-lac } \boldsymbol{Z} \\
\text { expression (MU) }\end{array}$ \\
\cline { 3 - 4 } & & Aerobic & Anoxic \\
\hline Minimal salts with & pBR322 (vector) & $22 \pm 1$ & $<1 \cdot 0$ \\
glycerol and fumarate & pGSG2 (blyX) & $<1 \cdot 0$ & $<1 \cdot 0$ \\
Luria-Bertani & pBR322 (vector) & $43 \pm 1$ & $101 \pm 1$ \\
& pGSG2 (blyX) & $<1.0$ & $<1 \cdot 0$ \\
\hline
\end{tabular}

Table 5. Expression of frd'-lacZ in E. coli JRG1787( $($ (frd'-lacZ) $\Delta f n r)$ grown under anoxic conditions with plasmids pT51, pGS24 or pBR322 in the presence of various concentrations of the iron chelator 1,10-phenanthroline

\begin{tabular}{|cccc|}
\hline \multirow{2}{*}{$\begin{array}{c}\text { 1,10-Phenanthroline } \\
\text { concentration }\end{array}$} & \multicolumn{2}{c|}{$\boldsymbol{f r d} \boldsymbol{d}^{\prime}$-lacZ expression (MU) } \\
\cline { 2 - 4 } & pT51 $\left(\boldsymbol{h l y} \boldsymbol{y} \boldsymbol{X}^{+}\right)$ & pGS24 $\left(\boldsymbol{f n} \boldsymbol{r}^{+}\right)$ & pBR322 \\
\hline $0 \mu \mathrm{M}$ & 980 & 1580 & 160 \\
$10 \mu \mathrm{M}$ & 130 & 970 & 60 \\
$20 \mu \mathrm{M}$ & 110 & 130 & 60 \\
$50 \mu \mathrm{M}$ & 100 & 140 & 60 \\
$50 \mu \mathrm{M}+50 \mu \mathrm{M}$ iron & 610 & 1400 & 170 \\
\hline
\end{tabular}

expression could be measured when cells were grown under anoxic conditions; low levels were detected under aerobic conditions. By contrast, in LB medium, expression of the $b l y X p-l a c Z$ promoter fusion was greatest when cells were grown under anoxic conditions.

\section{Regulation of frdA'-lacZ expression in the presence of iron chelators}

E. coli JRG1787 ( $\left.\Phi\left(f r d A^{\prime}-l a c Z\right) \Delta f n r\right)$ was used to study the effects of iron limitation on the regulation of the frd $A^{\prime}$-lac $Z$ expression by HlyX; FNR was included as a control (Table 5). The iron chelator 1,10-phenanthroline reduced cell growth and expression of $f r d A^{\prime}-l a c Z$ in a concentration-dependent manner. Growth was reduced gradually with increasing 1,10-phenanthroline concentrations under aerobic conditions whereas concentrations of $20 \mu \mathrm{M}$ phenanthroline or greater abolished growth abruptly under anoxic conditions. Addition of excess iron completely abrogated the effect of $20 \mathrm{mM} \mathrm{1,10-}$ phenanthroline. This result suggests that the the effect of 1,10-phenanthroline under aerobic conditions is due to generalized iron limitation whereas the effect under anoxic conditions is due to inactivation of the FNR and HlyX proteins and/or direct or indirect reduction in the activity of iron-containing anaerobic respiratory enzymes.

The nontoxic chelator Chelex-100 reduced frd $A^{\prime}-l a c Z$ expression and cell growth in a similar manner (data not shown). However, there was only a moderate reduction in growth and expression of $f r d A^{\prime}-$ lac $Z$ as compared to 1,10 phenanthroline-treated cultures. Again, the inhibition of growth and $f r d A^{\prime}-l a c Z$ expression could be completely reversed by the addition of excess iron.

\section{DISCUSSION}

\section{Regulation of expression of haemolytic activity by HlyX}

HlyX, but not FNR, was able to activate haemolytic activity in E. coli, and the activity could only be detected in cells grown under anoxic conditions (Fig. 1). The haemolytic activity peaked in the late exponential phase and dropped slightly during the stationary phase, suggesting that expression ceases or is reduced after the exponential phase. The same pattern of expression was also seen with $\operatorname{frd} A^{\prime}-l a c Z$. To date, it has not been possible to characterize the HlyX-induced haemolytic activity. Although the activity is fairly stable and easily followed through various purification steps, the protein is present in vanishingly small quantities.

\section{Regulation of gene expression under different growth conditions}

Under anoxic conditions, HlyX protein activated frd $A^{\prime}-$ lac $Z$ in E. coli JRG1787 approximately half as well as FNR (Table 3). The lower levels of gene activation may be a function of concentration or the ability of HlyX to interact with $E$. coli promoters or polymerase. In cells lacking both the HlyX and FNR proteins, frd $A^{\prime}-$ lac $Z$ expression was activated threefold under anoxic conditions as compared to aerobic conditions. This result suggests that some other redox-sensitive mechanism also affects $f r d A^{\prime}-$ lac $Z$ expression.

Carbon source and, to some extent, growth phase affected HlyX-and FNR-dependent regulation of the frd $A^{\prime}-l a c Z$ gene (Fig. 2). In cultures containing glucose, the expression of $\operatorname{rd} A^{\prime}-l a c Z$ was relatively constant during the exponential growth phase $(1-8 \mathrm{~h})$. With glycerol as a carbon source, frd $A^{\prime}$-lac $Z$ expression increased steadily as the cells grew exponentially $(5-20 \mathrm{~h})$. Although the levels of $f r d A^{\prime}-l a c Z$ expression were lower at early time points, maximal expression was always detected in glycerol rather than glucose medium. The effector of this carbon-sourcedependent regulation may be the CRP protein, since the putative FNR target sequences in the frd $A$ promoter have approximately the same level of homology with the CRP consensus sequence as with the FNR consensus sequence (Spiro \& Guest, 1990). Alternatively, the effect might be indirectly mediated by cAMP (Unden \& Duschene, 1987). The nature of the growth-phase-dependent effector is unclear but it may be a regulatory protein responsive to fumarate concentration. Another possible explanation is that the Miller (1972) assay, which uses $A_{600}$ to estimate total cellular protein, may have over-estimated frd $A^{\prime}-l a c Z$ expression because of alterations in the cell surface (e.g. capsule) of glycerol- versus glucose-grown cells. 


\section{Autoregulation of hlyX gene expression}

The promoter of the FNR gene contains an FNR consensus sequence, and Spiro \& Guest (1987) reported that under anoxic conditions, expression of an fnr-lac $Z$ promoter fusion was reduced in $f n r^{+}$strains, but not in $\Delta f n r$ strains. In similar experiments, Pascal et al. (1986) found that the expression of $f n r$ was negatively regulated by its own product but expression was independent of anaerobiosis. Others have reported that fnr-specific mRNA levels and the abundance of the FNR protein are not significantly affected by changes in oxygen tension (Unden \& Duschene, 1987; Eiglmeier et al., 1989).

The promoter region of the $b l y X$ gene contains a region of dyad symmetry immediately downstream of a putative -10 region, which is almost identical to the FNR consensus sequence (MacInnes et al., 1990). In the absence of the HlyX protein, the blyXp-lac $Z$ promoter fusion was expressed in both $L B$ and minimal salts medium; however, the pattern of expression was reversed. In LB medium, $b l y X p-l a c Z$ expression was highest when cells were grown under anoxic conditions, whereas in minimal medium, bly $X p-l a c Z$ expression could only be detected in aerobic cultures. Taken together, these data suggest that the bly $X$ gene product is able to repress its own synthesis under both aerobic and anaerobic conditions; however, the basal level of bly $X$ transcription is a function of not only oxygen levels, but also growth conditions.

\section{Role of iron in HlyX-regulated gene expression}

Consistent with previous studies on FNR, the activation of the frd $A^{\prime}-$ lac $Z$ operon promoter by the HlyX was iron dependent (Table 5; Green et al., 1991; Trageser \& Unden, 1989). Since the chelator 1,10-phenanthroline is known to have toxic and DNA-damaging properties in bacterial cells (Sigman et al., 1979) these experiments were repeated with the Chelex-100, an iron chelator, attached to latex beads, which does not enter the bacterial cell. The effects of iron chelation with Chelex-100 were consistent with those obtained using 1,10-phenanthroline, but were much less pronounced.

The identity of the latent haemolytic activity induced in E. coli is not yet known. Frey et al. (1989) suggested that the blyX gene, which they call the cfp (CAMP factor protein) gene, encodes a CAMP cohaemolysin. They reported that this cohaemolysin is antigenically related to protein B of Streptococcus agalactiae, and it is able to produce a distinct CAMP reaction in the presence of both phospholipase $\mathrm{C}$ and phospholipase D. Although blyX ( $c f p$ appears to induce (rather than to actually encode) a haemolysin, the E. coli gene activated by HlyX could encode a protein which is related to protein $\mathrm{B}$ or other CAMP factors. It is likely that there is also a similar HlyXregulated gene in $A$. pleuropneumoniae. Convalescent serum from $A$. pleuropneumoniae-infected animals can neutralize the haemolytic activity induced by HlyX. Furthermore, Frey et al. (1989) found that antiserum produced against $E$. coli containing the $c f p$ gene was able to neutralize the CAMP reaction of $A$. pleuropneumoniae strains.
Recently, a similar fnr homologue has been cloned from Bordetella pertussis, btr (Bordetella transcriptional regulator), and from Haemophilus ducreyi (Bannan et al., 1993; P. A. Totten, personal communication). These genes are also able to induce haemolytic activity in E. coli, and $b t r$ has been shown to complement E. coli fnr mutants (Bannan $e t$ al., 1993). It might be noted that although $B$. pertussis, $A$. pleuropneumoniae and probably $H$. ducreyi all have one or more related haemolysins (belonging to the RTX family) there is no evidence that $f n r$-like genes are involved in the regulation of their expression (Ehrmann et al., 1991; Frey et al., 1993a). The role of these 'haemolysin-inducing' FNR homologues in virulence remains to be established.

\section{ACKNOWLEDGEMENTS}

We thank J. R. Guest, R. P. Gunsalus and A. M. Kropinski for their generous gifts of E. coli strains, plasmids and phage, and P. H. S. Ling for technical assistance. We are also grateful to P. A. Totten for sharing unpublished results. Financial support for this work was provided by a grant from the Natural Sciences and Engineering Research Council of Canada.

\section{REFERENCES}

Bannan, J. D., Moran, M. J., Maclnnes, J. I., Soltes, G. A. \& Friedman, R. L. (1993). Cloning and characterization of btr, a Bordetella pertussis gene encoding an FNR-like transcriptional regulator. J Bacteriol 175, 7228-7235.

Batut, J., Daveran-Mingot, M.-L., David, M., Jacobs, J. \& Garnerone, A. M. (1989). fixK, a gene homologous with $f n r$ and $c r p$ from Escherichia coli, regulates nitrogen fixation genes in Rbizobium meliloti. EMBO J 5, 1279-1286.

Bolivar, F., Rodriguez, R. L., Greene, P. J., Betlach, M. C., Hayneker, H. L., Boyer, H. W. \& Falkow, S. (1977). Construction and characterization of new cloning vehicles. II. A multipurpose cloning system. Gene 2, 95-113.

Casadaban, M. (1976). Transposition and fusion of the lac genes to selected promoters in Escherichia coli using bacteriophage lambda and Mu. J Mol Biol 104, 541-555.

Colonna-Romano, S., Arnold, W., Schluter, A., Boistard, P., Püler, A. \& Preifer, U. B. (1990). An Fnr-like protein encoded in Rbizobium leguminosarum biovar viciae shows structural and functional homology to Rbizobium meliloti FixK. Mol \& Gen Genet 223, 138-147.

Cotter, P. A., Chepuri, V., Gennis, R. B. \& Gunsalus, R. P. (1990). Cytochrome o (cyo $A B C D E)$ and $\mathrm{d}(c y d A B)$ oxidase gene expression in Eschericbia coli is regulated by oxygen, $\mathrm{pH}$, and the fnr gene product. J Bacteriol 172, 6333-6338.

Ehrmann, I. E., Gray, M. C., Gordon, V. M., Gray, L. S. \& Hewlett, E. L. (1991). Hemolytic activity of adenylate cyclase toxin of Bordetella pertussis. FEBS Lett 278, 79-83.

Eiglmeier, K., Honore, N., luchi, S., Lin, E. C. \& Cole, S. T. (1989). Molecular genetic analysis of Fnr-dependent promoters. Mol Microbiol 3, 869-878.

Frey, J. \& Nicolet, J. (1988). Regulation of hemolysin expression in Actinobacillus pleuropneumoniae serotype 1 by $\mathrm{Ca}^{2+}$. Infect Immun 56, $2570-2575$.

Frey, J., Perrin, J. \& Nicolet, J. (1989). Cloning and expression of a cohemolysin, the CAMP factor of Actinobacillus pleuropneumoniae. Infect Immun 57, 2050-2056.

Frey, J., Stucki, U. \& Nicolet, J. (1993a). Analysis of hemolysin operons in Actinobacillus pleuropneumoniae. Gene 123, 51-58. 
Frey, J., Bosse, J. T., Chang, Y.-F., Cullen, J. M., Fenwick, B., Gerlach, G. F., Gygi, D., Haesebrouck, F., Inzana, T. J., Jansen, R., Kamp, E. M., Macdonald, J., Macinnes, J. I., Mittal, K. R., Nicolet, J., Rycroft, A., Segers, R. P. A. M., Smits, M. A., Stenbaek, E., Struck, D. K., van den Bosch, J. F., Willson, P. J. \& Young, R. (1993b). Actinobacillus pleuropneumoniae RTX toxins: uniform designation of haemolysins, cytolysins, pleurotoxin and their genes. $J$ Gen Microbiol 139, 1723-1728.

Galimand, M., Gamper, M., Zimmerman, A. \& Haas, D. (1991). Positive, FNR-like control of anaerobic arginine degradation and nitrate respiration in Pseudomonas aeruginosa. $J$ Bacteriol 173, 1598-1606.

Green, J., Trageser, M., Six, S., Unden, G. \& Guest, J. R. (1991). Characterization of the FNR protein of Escherichia coli, an ironbinding transcriptional regulator. Proc $\mathrm{R}$ Soc Lond B Biol Sci 244, 37-144.

Green, J., Sharrocks, A. D., Macinnes, J. I. \& Guest, J. R. (1992). Purification of Hly X, a potential regulator of haemolysin synthesis, and properties of HlyX:FNR hybrids. Proc R Soc Lond B Biol Sci 248, 79-84.

Hassan, H. M. \& Sun, H.-C. (1992). Regulatory roles of Fnr, Fur, and Arc, in expression of manganese-containing superoxide dismutase in Escherichia coli. Proc Natl Acad Sci US A 89, 3217-3221.

Inzana, T. J. (1991). Virulence properties of Actinobacillus pleuropneumoniae. Microb Pathog 11, 305-316.

Jones, H. M. \& Gunsalus, R. P. (1985). Transcription of the Eschericbia coli fumarate reductase genes $(f r d A B C D)$ and their coordinate regulation of oxygen, nitrate, and fumarate. $J$ Bacteriol 164, 1100-1109.

Koch, A. L. (1981). Growth measurement. In Manual of Methods for General Bacteriology, pp. 179-207. Edited by P. Gerhardt, R. G. E. Murray, R. N. Costilow, E. W. Nester, W. A. Wood, N. R. Kreig \& G. B. Phillips. Washington DC: American Society for Microbiology.

Lambden, P. R. \& Guest, J. R. (1976). Mutants of Escherichia coli $\mathrm{K} 12$ unable to use fumarate as an anaerobic electron acceptor. $J \mathrm{Gen}$ Microbiol 97, 145-160.

Lian, C.-J., Rosendal, S. \& Maclnnes, J. I. (1989). Molecular cloning and characterization of a haemolysin gene from Actinobacillus (Haemophilus) pleuropneumoniae. Infect Immun 57, 3377-3382.

Macinnes, J. I., Kim, J. E., Lian, C.-J. \& Soltes, G. A. (1990). Actinobacillus pleuropneumoniae blyX gene homology with the fnr gene of Escherichia coli. J Bacteriol 172, 4587-4592.

Miller, J. H. (1972). Assay of $\beta$-galactosidase. In Experiments in Molecular Genetics, pp. 352-355. Edited by J. H. Miller. Cold Spring Harbor, NY: Cold Spring Harbor Laboratory.

Nicolet, J. (1992). Actinobacillus pleuropneumoniae. In Diseases of Swine, 7th edn, pp. 401-408. Edited by A. D. Leman, B. E. Straw, W. L. Mengeling, S. d'Allaire \& D. J. Taylor. Ames, Iowa: Iowa State L'niversity.

Pascal, M., Bonnefoy, V., Fons, M. \& Chippaux, M. (1986). Use of gene fusions to study the expression of $f n r$, the regulatory gene of anaerobic electron transfer in Escherichia coli. FEMS Microbiol Lett 36, 35-39.

Rosendal, S., Devenish, J., Macinnes, J. I., Lumsden, J. H., Watson, S. \& Xun, H. (1988). Evaluation of heat-sensitive neutrophil-toxic and hemolytic activity of Actinobacillus pleuropneumoniae. Am J $\checkmark$ et Res 49, 1053-1058.

Sambrook, J., Fritsch, E. F. \& Maniatis, T. (1989). Molecular Cloning: $A$ Laboratory Manual, 2nd edn. Cold Spring Harbor, NY: Cold Spring Harbor Laboratory.

Sawers, R. G. (1991). Identification and molecular characterization of a transcriptional regulator from Pseudomonas aeruginosa PAO1 exhibiting structural and functional similarity to the FNR protein of Escherichia coli. Mol Microbiol 5, 1469-1481.

Schneider, K. \& Beck, C. F. (1986). Promoter-probe vectors for the analysis of divergently arranged promoters. Gene 42, 37-48.

Sharrocks, A. D., Green, J. \& Guest, J. R. (1991). FNR activates and represses in vitro. Proc R Soc of Lond B Biol Sci 245, 219-226.

Shaw, D. \& Guest, J. R. (1982). Nucleotide sequence of the Fnr protein and primary structure of the Fnr protein of Escherichia coli. Nucleic Acids Res 10, 6119-6131.

Sigman, D. S., Graham, R. D., d'Aurora, V. \& Stern, A. M. (1979). Oxygen-dependent cleavage by the 1,10-phenanthroline-cuprous complex. J Biol Chem 254, 12269-12272.

Spiro, S. (1994). The FNR family of transcriptional regulators. Antonie Leeuwenboek (in press).

Spiro, S. \& Guest, J. R. (1987). Regulation and over-expression of the $f n r$ gene of Escherichia coli. J Gen Microbiol 133, 3279-3288.

Spiro, S. \& Guest, J. R. (1988). Inactivation of the FNR protein of Escherichia coli by targeted mutagenesis in the $\mathrm{N}$-terminal region. Mol Microbiol 2, 701-707.

Spiro, S. \& Guest, J. R. (1990). FNR and its role in oxygen-mediated gene expression in Escherichia coli. FEMS Microbiol Rev 75, 399-428.

Spiro, S. \& Guest, J. R. (1991). Adaptive responses to oxygen limitation in Escherichia coli. Trends Biochem Sci 16, 310-314.

Spiro, S., Roberts, R. E. \& Guest, J. R. (1989). FNR-dependent repression of the $n d h$ gene of Escherichia coli and metal ion requirement for $f n r$-regulated gene expression. Mol Microbiol 3, 601-608

Trageser, M. \& Unden, G. (1989). Role of cysteine residues and of metal ions in the regulatory functioning of FNR, the transcriptional regulator of anaerobic respiration in Escherichia coli. Mol Microbiol 3, 593-599.

Unden, G. \& Duschene, A. (1987). On the role of cyclic AMP and the Fnr protein in Escherichia coli growing anaerobically. Arch Microbiol 147, 195-200.

Received 18 August 1993; revised 11 October 1993; accepted 20 October 1993. 